\title{
序文 企画のねらい
}

\author{
加 藤 明 彦
}

浜松医科大学医学部附属病院血液浄化療法部

今回，特集号のテーマとして「AKI (急性腎障害)」を取りあげた．本邦では，2016 年に日本腎臓学会，日本集 中治療医学会, 日本透析医学会, 日本急性血液浄化学会, 日本小児腎臓病学会の関連 5 学会により,「AKI（急性腎 障害）診療ガイドライン 2016」が作成され，AKIへの関心はますます高まっている.

従来の急性腎不全（acute renal failure：ARF）の概念は, 第二次世界大戦中のロンドン空襲の際にクラッシュ症 候群によって無尿になり，剖検で急性尿細管壊死と考えられる病変がみられたことに端を発している。しかし， ARF には統一された診断基準や病期分類がなく, そのことが疫学研究や治療法の開発, ひいては予後改善の妨げに なっていると指摘されていた。 そうした中, 2004 年にRIFLE（Risk, Injury, Failure, Loss of kidney function and End stage of kidney disease) 分類によるAKI の概念が初めて提唱され，2007 年に AKIN (Acute Kidney Injury Network）分類, 2012 年に KDIGO（Kidney Disease Improving Global Outcomes）分類が提唱された. KDIGO 分 類では, AKI の診断には血清クレアチニン増加率が重要であること, 腎機能低下は診断に必須でないこと, そ尿だ けでも診断可能であること，などが記載されている.

ARF から AKI に疾患概念が移行したことで, ここ十数年でいくつもの重要なことが明らかになっている。例え ば，1）早期かつ特異的な尿中バイオマーカー（L-FABP, NGAL）が開発され，保険診療で測定可能になった，2） AKI はCKDのリスク因子である，3）AKI は他の臓器障害と連関する，4）高齢者で AKI が多く，腎予後や生命予 後と関連する，などがあげられる.

本特集号では，「AKI（急性腎障害）診療ガイドライン作成委員会」のメンバーに執筆をお願いし，AKIについ てアップデートな知識を知っていただくことを目的に企画した. AKI の疾患概念と診断基準から疫学, 早期診断 マーカー, 予防・治療薬，急性血液浄化療法，栄養・代謝管理，長期予後，小児および高齢者への対応まで，「AKI (急性腎障害) 診療ガイドライン 2016」をほぼ網羅した内容になっている。ご一読いただければ，AKIはハイリス クの common diseaseであり, 透析医療スタッフが知っておくべき疾患群であることが理解いただけると思う. 是非，本特集号を毎日の診療にお役立ていただければ幸甚である.

利益相反 (COI) : 申告すべきものなし.

加藤 明彦 浜松医科大学医学部附属病院血液浄化療法部 † 431-3192 静岡県浜松市東区半田山 1-20-1

Akihiko Kato Tel \& Fax: 053-435-2756 E-mail: a.kato@hama-med.ac.jp 